І. О. Іншакова, К. Ю. Стахова

\title{
СТРУКТУРНО-СЕМАТИЧНІ ОСОБЛИВОСТІ ЛЕКСИКИ НА ПОЗНАЧЕННЯ СТРАВ УКРАЇНСЬКОГО НАРОДУ В КУЛІНАРНИХ КНИГАХ
}

Іншакова І. О., Стахова К. Ю. Структурно-семантичні особливості лексики на позначення страв українського народу в кулінарних книгах.

У статті проаналізовано структурно-семантичні типи найменувань українських страв у кулінарних книгах, 3'ясовано їх граматичні особливості. Акцентовано на граматичному аспекті, зокрема на однослівних/ двослівних (елементарних) та аналітичних (неелементарних) структурах, що мають головний та залежний компоненти. Досліджено основні типи елементарних структур. За семантичними особливостями диференційовано: 1) лексику на позначення перших страв; 2) лексику на позначення других страв; 3) лексику на позначення страв 3 борошна та сиру; 4) лексику на позначення молочних страв; 5) лексику на позначення напоїв. Увагу зосереджено на перших двох типах. 
Ключові слова: лексика на позначення страв, народна кулінарна номенклатура, структурно-семантичні особливості, лексема, семантика, мотивація, граматичний аспект.

Иншакова И. А., Стахова К. Ю. Структурно-семантические особенности лексики для обозначения блюд украинского народа в кулинарных книгах.

В статье анализируются структурно-семантические типы наименований украинских блюд в кулинарных книгах, определены их грамматические особенности. Акцентируется внимание на грамматическом аспекте, в частности на однословных / двухсловных (элементарных) и аналитических (неэлементарных) структурах, которые имеют главный и зависимый компоненты. Исследуются основные типы элементарных структур. За семантическими особенностями дифференцируются: 1) лексика для обозначения первых блюд; 2) лексика для обозначения вторых блюд; 3) лексика для обозначения блюд из муки и сыра; 4) лексика для обозначения молочных блюд; 5) лексика для обозначения напитков. Внимание сосредотачивается на первых двух типах.

Ключевые слова: лексика для обозначения блюд, народная кулинарная номенклатура, структурно-семантические особенности, лексема, семантика, мотивация, грамматический аспект.

Inshakova I. O., Stahova K. Yu. Structural-semantic features of vocabulary on the designation of dishes of the Ukrainian people in culinary books.

Thematic group of vocabulary on the designation of dishes is closely linked to the material culture of the people, which makes it possible to define it as a historical category and preserves information about the original folk culture, responds to socioeconomic, cultural and historical changes in society. It is one of the oldest layers of Slavic vocabulary, which dates back to the Slavonic period, or even the Prido-European period. This allows us to investigate the patterns of formation and development of this group of vocabulary, to identify structural and semantic features, and others.

The processes of occurrence of food, dishes and drinks, their formation and development, functioning in certain historical periods, their names were and are the subject of research of scientists of various branches of knowledge, in particular ethnologists, historians, sociologists, linguists, etc. Such intelligence is important for gastronomy: linguistic and culturological analysis form part of this "culinary" science.

Equally important is the "culinary terminology" in scientific literature, in particular in recipes. A comparative analysis of culinary books, recipes books makes it possible to distinguish between common and excellent nominations that have structural and semantic peculiarities, their history of occurrence, and undergo certain changes.

The book of recipes by S. Klinovetsky, one of the first Ukrainian culinary books, fully reveals the vocabulary group on the designation of dishes. According to the structural type, culinary terminology is represented by two groups: elementary (one /

() І. О. Іншакова, К. Ю. Стахова, 2018. -34- 
two-component) phrases and non-elemental (complex) three / four-component phrases. Among them, the most common are: noun-noun and noun-adjective (adjectival) phrases. The semantic nature of the nominations is motivated by the main component of the dish, the qualitative characteristic of the dishes (color, shape, texture, size, taste), the way of cooking, the purpose of another product / dish and ethnonim, which denotes the Ukrainian social color. At present, it is relevant to study the subject-thematic group of vocabulary on the designation of dishes and beverages, which is an element of the material and spiritual culture of the people.

Key words: vocabulary on the designation of dishes, folk culinary nomenclature, structural-semantic features, lexeme, semantics, motivation, grammatical aspect.

Народна кулінарна номенклатура $\epsilon$ досить важливою у складі лексичної системи. Їжа є елементом не лише матеріальної, а й духовної культури народу. Процеси суспільства впливають на культуру народу, де вагоме місце посідає культура харчування, яка також зазнає певних змін. Ці зміни приводять до архаїзації лексики досліджуваних груп, до появи нових назв.

Нині науковці більш активно досліджують тематичне групування, аналіз окремих лексичних груп слів, встановлення різних типів взаємовідношень між значеннями.

Лексика на позначення страв є невід'ємним складником мовної картини світу. Значну роль у дослідженні цієї групи лексики має культурологічний аспект, який засвідчує збереження традицій народу, що складають його самобутність та відрізняють від інших етносів. Саме тому дослідження відповідної лексики актуалізується не лише в галузі кулінарії, а й в царинах етнології й етнографіï.

Назви їжі та напоїв були предметом мовознавчих студій у синхронії й діахронії на матеріалі різних мов (праці Л. Анохіної,
Г. Вешторт,
В. Губаревої,
С. Дмитрієвої,
Н. Ільїнської,

Т. Карасьової,

3. Козиревої,

О. Крижко,

О. Малоземліної, В. Невойт, Н. Никитенко, Л. Ура та ін.). Низка науковців аналізує лексику на позначення страв та напоїв 3 позицій діалектології. Наприклад, лексику на говірковому матеріалі розглядали Ф. Бабій, 3. Бичко, М. Волошинова, Г. Врублевська, Й. Дзендзелівський, 
А. Майборода, М. Тимченко, С. Яценко та ін. Системний аналіз народної кулінарної номенклатури здійснили Є. Турчин (на матеріалі східнополіських говірок), 3. Ганудель (на матеріалі українських говірок Східної Словаччини), Е. Гоца (на матеріалі закарпатських говірок).

Дослідження цієї групи лексики виявлено в художніх та наукових текстах, зокрема, у працях О. Остроушко «Структурні типи назв страв у «Практичній кухні» Ольги Франко», С. Яценка «Гуцульські назви продуктів харчування страв і напоїв у романі Петра Шекерика-Доникова «Дідо Іванчик». Науковці розглядали лексеми з різних аспектів, зазначали мотивацію лексем, їх роль та функціонування в текстах.

Актуальність нашого дослідження виявляється в тому, що група лексики на позначення страв досі не має чіткого розмежування, структурного вираження в науковій літературі. У зв'язку 3 цим $€$ необхідність проаналізувати структурносемантичні особливості лексем, що повно розкривають групу лексики на позначення страв на сторінках однієї 3 перших українських кулінарних книг.

Мета дослідження полягає в тому, щоб з'ясувати структурно-семантичні та граматичні особливості лексики на позначення страв українського народу. Матеріалом дослідження слугують номінації на позначення перших i других страв кулінарної термінології. Проаналізовано близько 90 номінацій. Джерельною базою послугували кулінарні книги 3. Клиновецької «Страви й напитки на Україні» / 3. Клиновецька. - Київ : Час, 1991. - 215 с.; «Українські страви» (Третє видання). - К. : Державне видавництво технічної літератури УРСР, 1960. - 454 с.

Невід'ємну частину лексичного складу кожного народу становлять назви їжі та напоїв. Немає чіткого розмежування категорій кулінарної номенклатури, але в українського народу усталено функціонують: 1) назви перших / других страв; 2) назви десертних страв (солодкі страви / напої та ін.).

ㄷ І. О. Іншакова, К. Ю. Стахова, 2018. -36- 
Аналізуючи групу лексики на позначення страв, слід звертати увагу на лексико-семантичний та граматичний аспекти. Лексико-семантичний аспект дослідження виявляється в найменуваннях, об'єднаних спільною семантичною ознакою, у диференціації різних мотивувальних ознак, які лежать в основі найменувань: спільний продукт, форма, якість, смак, вигляд, спосіб приготування й призначення / використання страви чи продукту. Деякі з назв є нормою літературної мови, частина, як народно-розмовні, - спільні для окремих говірок.

Граматичний аспект побудований на основі структурного методу. У зв'язку з цим лексика на позначення страв представлена двома групами: однослівними / двослівними (елементарними) та аналітичними (неелементарними), що мають головний та залежний компоненти. Односкладні структури - це відіменникові чи віддієслівні словосполучення. Основними типами двоскладних (елементарних) структур $є$ такі: іменниково-прикметникові (дієприкметникові), іменниково-іменникові, іменниковоприслівникові.

Згідно 3 позицією 3. Клиновецької, до лексики на позначення страв та напоїв відносимо:

1) лексику на позначення перших страв;

2) лексику на позначення других страв;

3) лексику на позначення страв з борошна та сиру;

4) лексику на позначення молочних страв;

5) лексику на позначення напоїв.

Предметно-тематична група лексики на позначення страв має складну структуру, що дає змогу виокремити такі різновиди:

1) лексика на позначення перших страв;

2) лексика на позначення других страв: а) каші та бабки; б) підлива та городина;

3) лексика на позначення страв $з$ борошна та сиру: а) хліб, булки, пиріжки; б) паски; в) солодке тісто;

4) лексика на позначення молочних страв; 
5) лексика на позначення напоїв.

Зібраний фактичний матеріал найменувань перших $\mathrm{i}$ других страв диференційовано за тематичними підгрупами. Кожне найменування можна досліджувати як на діахронному, так і на синхронному рівнях.

Функціонування давніх лексем на позначення страв, що вийшли з ужитку, та сучасних найповніше розкриває кулінарна книга 3. Клиновецької «Страви й напитки на Україні». Окрім того, використано й матеріал із книги «Українські страви» (1960р.), де подаються відомості 3 історії української кухні, лексеми на позначення страв української народної кухні, рецептура яких розроблена на основі поєднання відновленої рецептури із найпоширеніших тепер у Київській, Закарпатській, Львівській, Полтавській, Дніпропетровській, Запорізькій, Херсонській областях.

Лексика на позначення перших страв має свою специфіку. 3. Клиновецька виокремлює п'ятдесят сім перших страв, із яких найбільш виразними постають українські борщі та супи (юшки).

У текстах староукраїнської мови назву борщ уперше зафіксовано в 1598 році як демінутив: борщикъ (боръсчикъ): «тые хлопи з одное мисочки поливку албо борщик хлепчют» (3, III, с. 38). Слово вживалося на позначення рослини, але з часом змінилося: «юшка із буряка та капусти». Зараз маємо лексему «борщз». Кулінарні книги подають низку борщів, що мають свої відмінності. Зважаючи на називання страви та ії значення, лексему «борщ» можна класифікувати за такими ознаками:

- за стрижневим компонентом - борщ буряковий з грибами, борщ з карасями, борщз з чорносливом, борщ з квашеними яблуками, борш з м'ясними галушками (4, с. 444);

- за способом приготування - 1) варіння + смаження - бори з потрухами (1, с. 3); борщ чернігівський (1, с. 2); борм кубанський $(1$, с. 2); борш пісний з вушками $(1$, с. 3$)$; 2) варіння + випікання борщ без м'яса $(1$, с. 3); 3) варіння + тушкування - борм волинський $(1$, с. 2$)$; борщч київський з куркою (1, с. 2-3); 4) варіння

(ㄱ.. О. Іншакова, К. Ю. Стахова, 2018. -38- 
- борщ зелений $(1$, с. 3). Зафіксовані інфінітивні форми: зварити, покришити, підсмажити, заправити, всипати, протерти, вкидати, ліпить, спекти, затовкти, забілити, кипіти, улить;

- за етнонімом - борщ український «рідка страва, що вариться 3 посічених буряків, капусти 3 додатком картоплі та різних приправ» (2, I, с. 222); борщ київський «борщ із яловичиною, iз тушкованих буряків, 3 томатом та кислими яблуками» (4, с. 90); борщ полтавський «борщ 3 гусятиною чи курятиною, із додаванням галушок» $(4$, с. 90); борщ чернісівський «борщ 3 м'ясом, буряком, квасолею, яблуками та помідорами» $(4$, c. 92$)$;

- за кольором - червоний борм «борщ із червоних буряків» (5, с. 91); зелений борщ «борщ зі щавлю» (5, с. 91); рожевий борм «борщ із буряків та 3 помідорами» $(5$, с. 91$)$; помаранчевий борщ «борщ 3 томатною пастою та свіжою капустою» (4, с. 89); білий борщ «борщ із капусти» $(5$, с. 91$)$; чорний борщ «борщ із червоних буряків та з кров'ю забитого кабана» $(5$, с. 91$)$.

Отже, створенню цієї класифікації сприяла розгалужена семантика лексеми «борщ». Назви страви мотивовані стрижневим компонентом, способом приготування, етнонімом та кольором, що повно розкриває семантику лексеми «борщ».

Здавна лексема юха (від псл. *juxa) позначала будь-який навар - м'ясний, рибний, рослинний. У давньоукраїнській мові функціонувала лексема $y x a$ з початковим $y$ та первинною семантикою, вона зафіксована на позначення відвару із сухих фруктів, який нині має назву компот. У сучасній українській мові форма юшка стала нормою й позначає м'ясний, картопляний, рибний та інші супи, а також рідину в будь-якій приготовленій їжі (2, XI, c. 617-618).

Лексема «юшка» в кулінарній книзі 3. Клиновецької складене найменування. Наприклад, із 17 найменувань 12 двокомпонентні (складаються із двох слів) та мотивовані:

- стрижневим компонентом страви: овочі - юшка 3 
квасолею, юшка з картоплею (1, с. 7); м’ясо - юшка з куркою $(1$, с. 7$)$; рослина - юшка з пастернаком $(1$, с. 7$)$, юшка з корінням $(1$, c. 6);

- етнонімом: назва місцевості - юшка київська (4, с. 110); передає «український соціальний колорит» - юшка гетьманська (1, с. 6).

Решта, 5 найменувань - багатокомпонентні найменування (складаються 33 слів), що мають два компоненти страви, один із яких головний, а другий - залежний від нього: юшка пшоняна 3 куркою $(1$, с. 7$)$ (вид каші + м'ясо); юшка яшна з кочеретою $(1$, с. 7$)$ (вид каші + овочі); юшка молочна з рижом (молоко + крупа) $(1$, c. 8). Найменування юшка $з$ квасолею або $з$ пастернаком $(1$, c. 7$)$ залежить від основного компонента страви.

Основними типами двокомпонентних словосполучень $є$ такі: іменниково-іменникові: юшка з корінням; юшка з куркою (Н. в. + О. в.) та іменниково-прикметникові: юшка яшна з кочеретою (Н. в. + О. в.). Загалом аналізована лексема являє собою двокомпонентну структуру, що мотивована основним компонентом страви та етнонімом.

Лексика на позначення других страв у кулінарній книзі 3. Клиновецької виокремлена в 6 розділах: смаженина, риба, підливи, городина, каші та бабки, закуски, що нараховують близько 400 лексем. Розділ «Каші та бабки» нараховує 47 найменувань, 3-поміж яких: 27 - каші, 20 - бабки.

Назва каша - праслов'янська: псл. kaša зіставляють 3 лит. $k o ́ s ̌ t i$ «цідити» й реконструюють початкове значення «просіяне потовчене зерно» або «проціджена (густа) їжа». Найулюбленішою на всій території України була гречана каша, найменш популярними - манна та пшенична, оскільки пшеницю майже повністю переробляли на борошно. Однокомпонентні словосполучення, що називають різні види каш, мотивовані:

- формою та виглядом страви - лексема-омонім черв'ячки (1, с. 65) «гречана каша, протерта на решето, нагадує

ㄷ І. О. Іншакова, К. Ю. Стахова, 2018. -40- 
безхребетних»; за видом / виглядом страви - лексема-омонім тетеря (1, с. 66) «густа гречана каша»- семантичне перенесення на основі подібності виду (тетеря - птах);

- розміром страви - дзьобавка $(1$, с. 66) «дрібна пшенична каша»; росівниия $(1$, с. 66$)$, лизанка $(1$, с. 66$)$ «дрібна кукурудзяна каша-розмазня»;

- за смаком страви - киселиця $(1$, с. 66) «кукурудзяна каша 3 сушеними сливами, кисла на смак».

Багатокомпонентні словосполучення, що називають різні види каш, мотивовані:

- основним компонентом страви - двокомпонентне словосполучення гречана каша $(1$, с. 64); манна каша $(1$, с. 65); рябко з м'яса $(1$, с. 67); трикомпонентне словосполучення, де наявний головний та залежний компоненти страви пшоняна каша з вершками (1, с. 64); ямна каша зі сметаною (1, с. 65); пшоно 3 сушеними сливами (1, с. 65);

- призначенням (до іншого продукту, страви) - гречана каша до молока (1, с. 64); риж до сметани (1, с. 67) - іменниковоприйменникова конструкція: Р. в. + прийменник до.

За структурою однокомпонентні словосполучення суфіксальні утворення від дієслівних основ: дзьобавка, лизанка; від основ, що вказують на властивості страви (смак): киселичя; двокомпонентні словосполучення - іменниково-прикметникові конструкції: гречана каша; іменниково-іменникові конструкції: рябко з м'яса; трикомпонентне словосполучення - складна конструкція, що складається з опорного компонента та залежних супідрядних іменників, прикметників: ящна каша зі сметаною; пшоно з сушеними сливами.

Слово бабка етимологи виводять 3 псл. *baba «галушка, кругле печиво», пов'язане 3 основою псл. *bab «надуватися, розбухати, бути кулястим»; назву ба́бка також фіксують як: ба́бка «великоднє печиво», ба́бка «солодкий здобний високий білий хліб циліндричної форми, який випікають до Великодня». За 
кулінарними книгами, лексема бабка умовно поділяється на м'ясну: бабка з курки (1, с. 23), бабка-шарпанина (1, с. 32), бабка 3 кролика (4, с. 170) та солодку: бабка з маку (1, с. 76); бабка $з$ повидла (1, с. 76), бабка сирна запечена (4, с. 287) тощо.

За структурою найбільшу кількість становлять двокомпонентні словосполучення (15 назв). За типом двоскладних структур: іменниково-іменникові: бабка з булки (1, с. 69); бабка з рижу (1, с. 69); іменниково-прикметникові (дієприкметникові) бабка смаковита (1, с. 68); бабка гарбузова (1, с. 67); бабка сирна запечена (4, с. 287).

Аналітичні назви мотивовані:

- основним компонентом страви - хліб: бабка хлібна $з$ вишнями (1, с. 69); каша та крупа: бабка з рижу (1, с. 69); бабка манна або пшоняна (1, с. 71); овочі: бабка гарбузова (1, с. 67); бабка з моркви (1, с. 69); молоко: бабка сирна (1, с. 68); плоди дерев: бабка з горіхів (1, с. 70);

- якісною характеристикою страви (смак) - бабка смаковита (1, с. 68);

- способом приготування страви - бабка сирна запечена (4, c. 287);

- етнонімом - бабка гуиульська $(1$, с. 70$)$;

- призначенням (до іншого продукту, страви) - гречана бабка до вершків $(1$, с. 71$)$ - іменниково-прийменникова конструкція: Р. в. + прийменник до.

Отже, тематична група лексики на позначення страв тісно пов'язана 3 матеріальною культурою народу, що дає змогу визначити ії як категорію історичну та зберігає відомості про споконвічну народну культуру, реагує на соціально-економічні й культурно-історичні зрушення в суспільстві. Вона $є$ одним із найдавніших шарів слов'янської лексики, який сягає праслов'янського періоду, а то й праіндоєвропейського. Це сприяє дослідженню закономірностей становлення й розвитку цієї групи лексики, виявленню структурно-семантичних особливостей та ін.

ㄷ І. О. Іншакова, К. Ю. Стахова, 2018. -42- 
Не менш важливою є «кулінарна термінологія» в науковій літературі, зокрема, у книгах рецептів. Зіставний аналіз кулінарних книг дає змогу виокремити спільні та відмінні номінації, що мають структурно-семантичні особливості, свою історію виникнення та зазнають певних змін, що призводять до архаїзації лексики досліджуваної групи або навпаки, позначають нові поняття, які лише поодиноко зафіксовані в суспільстві.

Книга рецептів 3. Клиновецької, що $є$ однією 3 перших українських кулінарних книг, повно розкриває групу лексики на позначення страв. Проаналізовано більше 90 номінацій, із них більше 40 - лексика на позначення перших страв, майже 50 лексика на позначення других страв.

За структурним типом кулінарна термінологія представлена двома групами: елементарними (одно/двокомпонентними) словосполученнями, що побудовані за такими схемами: іменник (назва продукту) + прикметник або дієприкметник; іменник (назва страви) + відіменний прикметник від назви основного або додаткового компонента; іменниково-прийменникова конструкція у таких відмінках: 1) орудний відмінок із прийменником з (із); 2) родовий відмінок із прийменником з (iз); 3) родовий відмінок із прийменниками до, для; та неелементарними (складними) три / чотирикомпонентними словосполученнями. Серед них найбільш поширеними $є$ : іменниково-іменникові та іменниковоприкметникові (дієприкметникові) словосполучення.

Семантична природа номінацій мотивована основним компонентом страви, їх якісною характеристикою (кольором, формою, текстурою, розміром, смаком), способом приготування, призначенням щодо іншого продукту та етнонімом, що позначає український соціальний колорит. Нині $є$ актуальним вивчення предметно-тематичної групи лексики на позначення страв i напоїв, які $\epsilon$ елементом матеріальної та духовної культури українського народу. 


\section{Література}

1. Клиновецька 3. Страви й напитки на Україні / 3. Клиновецька. - К. : Час, 1991. $-215 \mathrm{c}$.

2. Словник української мови : в 11-и т. - К. : Наукова думка, 1970-1980. T. $1-11$.

3. Словник української мови XVI - першої половини XVII ст. : в 12-и т. Львів, 1994-2005. - Т. 1-12.

4. Українські страви. - К. : Державне вид-во технічної л-ри УРСР, 1960. [3-є вид.]. -454 с.

5. Яценко С. Староукраїнська спадщина в лексиці західнополіського діалекту / С. Яценко // Волинь філологічна : Текст і контекст. Західнополіські говірки в просторі та часі. - Луцьк, 2012. - Вип. 9. - С. 90-102.

Стаття надійшла до редакиії 05.03.2018 p. 